\title{
Tropical silviculture in dense African forest (Part 4)
}

René CATINOT

Director of Forestry Research, C.T.F.T. ${ }^{1}$

Translation by Ilona BossANYI ${ }^{2}$

Article previously published in French in the journal Bois et Forêts des Tropiques, $\mathrm{n}^{\circ} 103$, September-October 1965 : Catinot R., 1965. Sylviculture tropicale en forêt dense africaine. Bois et Forêts des Tropiques, 103 : 3-16. https://doi. org/10.19182/bft1965.103.a18949

1 C.T.F.T. : Centre Technique Forestier Tropical. The C.T.F.T. was incorporated into the CIRAD as a forestry department in 1984.

Bois et Forêts des Tropiques

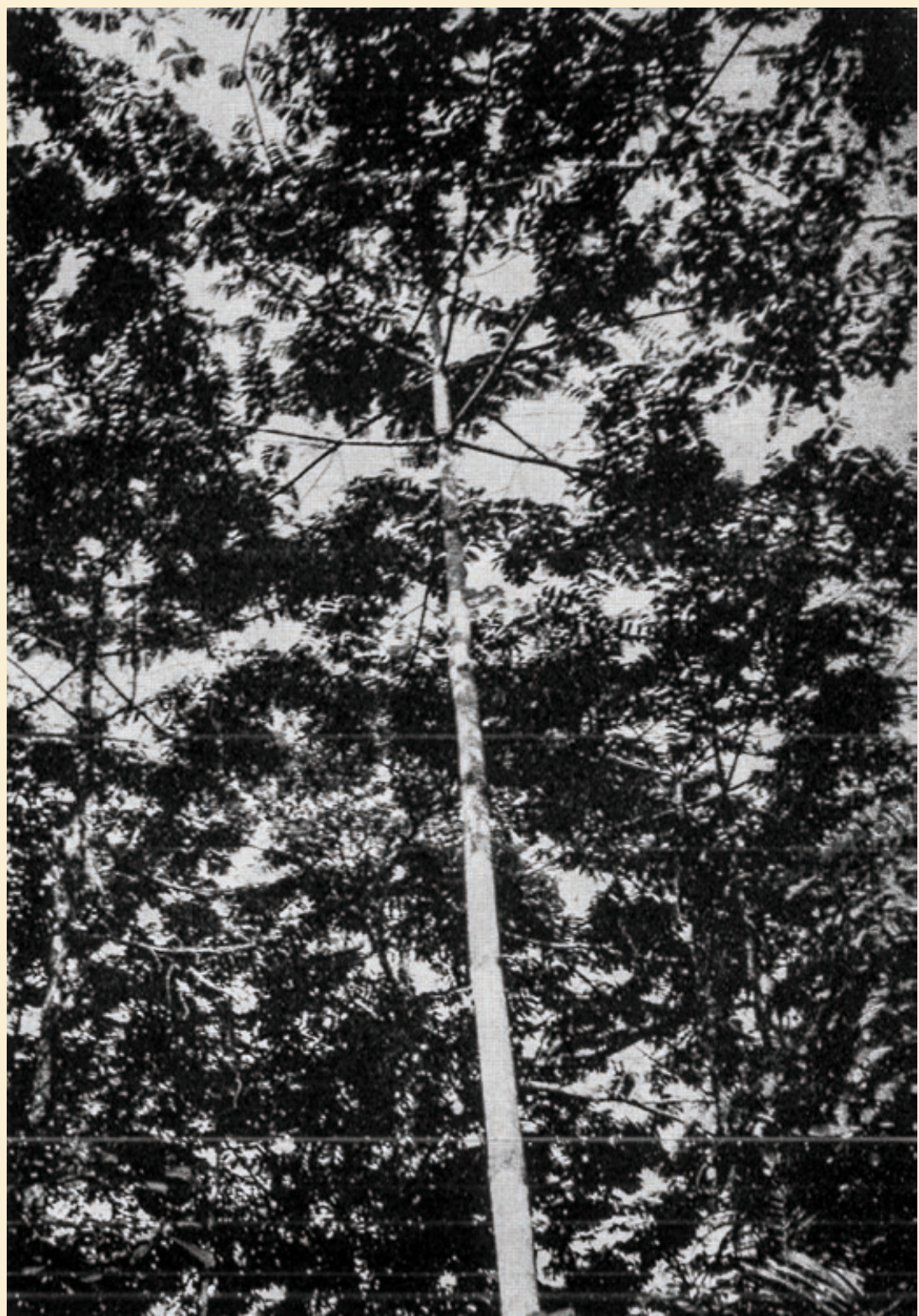

Photo 1.

An experimental parcel of 4-year-old llomba trees

(Pycnanthus angolensis (Welw.) Warb. subsp. angolensis).

Kribi reforestation (Cameroon).

Photo Brunck.

Doi : https://doi.org/10.19182/bft2018.336.a31613 - Droit d'auteur (C) 2018, Bois et Forêts des Tropiques (C) Cirad Date de publication : $1^{\text {er }}$ avril 2018

\section{Cirad ata}

(ब) $\mathbb{D} \Theta$

cence Creative Commons

Attribution - Pas de Modification 4.0 International.

Attribution-NoDerivatives 4.0 International (CC BY-ND 4.0)
Citer l'article / To cite the article

Catinot R., Bossanyi I., 2018. Tropical silviculture in dense African forest

(Part 4). Bois et Forêts des Tropiques, 336: 43-53. Doi: https://doi. org/10.19182/bft2018.336.a31613 


\section{RÉSUMÉ}

\section{Sylviculture tropicale en forêt dense africaine (partie 4)}

L'article présente la quatrième partie de l'étude sur la sylviculture en forêt dense africaine. Dans cet article, l'auteur compare les différentes méthodes employées dans les forêts tropicales humides à la lumière des résultats de recherche exposés dans le précédent article. II conclut que, excepté pour les méthodes "Limba » et "Okoumé », le principal facteur limitant le succès des plantations semble être le manque de lumière arrivant jusqu'au niveau du sol. Sur la base de cette observation fondamentale et d'autres considérations techniques, il propose des changements aux méthodes conventionnelles, avec la perspective d'améliorer leurs chances de succès.

Mots-clés : éclairement, dispositif expérimental, sylviculture, méthode, exploitation forestière, restauration forestière, plantation, productivité, forêt tropicale dense humide, Afrique.

\section{ABSTRACT}

\section{Tropicale silviculture in dense African forest (Part 4)}

The article presents the fourth part about tropical silviculture in dense African forest. In this part of this article, the author compares the different forestry methods employed in humid tropical forests in the light of the research results described in the previous article. He concludes that, except for the "Limba» and "Okoumé» methods, the main factor limiting the success of plantations seems to be the lack of light at ground level. Based on this fundamental observation and other technical considerations, he proposes changes to conventional methods with a view to improving their chances of success.

Keywords: enlightenment, experimental apparatus, forestry, method, logging, forest restoration, plantation, productivity, tropical humid forest, Africa.

\section{RESUMEN}

\section{Silvicultura tropical en bosque espeso de África (Parte 4)}

Este artículo es la cuarta parte sobre silvicultura tropical en bosques espesos de África. Aquí el autor compara los diferentes métodos forestales empleados en bosques tropicales húmedos a la luz de los resultados de las investigaciones descritas en el artículo precedente. Concluye que, excepto para los métodos «Limba» y «Okoumé», el principal factor limitador del éxito de las plantaciones parece ser la falta de luz a nivel del suelo. Sobre la base de esta observación fundamental y de otras consideraciones técnicas, sugiere cambios en los métodos convencionales con vistas a mejorar sus posibilidades de éxito.

Palabras clave: iluminación, aparato experimental, silvicultura, método, explotación forestal, restauración forestal, plantación, productividad, bosque húmedo tropical, África. 


\section{Research applications}

After describing the main silvicultural methods used in dense tropical forests in Africa, we reviewed current knowledge on the natural factors on which the success of forest plantations depends. Among these, light appears to be the determining factor. From our analysis of research conducted on this subject, we have drawn the following conclusions:

1. The amounts of light reaching a given point in an equatorial forest through gaps in the canopy of a given shape can be determined by calculations.

2. It is essential to check the resulting figures against accurate instrument measurements, which seems likely to be feasible in the near future.

3. In dense tropical forests, only very small amounts of light reach the forest floor ( 1 to $4 \%$ ); this can only be a considerable hindrance to the growth of seedlings that have germinated below the canopy.

4- The amounts of light that the different silvicultural methods can provide to naturally-growing introduced plants are highly variable, but often seem inadequate (5\% to $20 \%$ ).

5. The optimum amounts of light required by the main commercial forest species are not known, and studies are under way to fill this regrettable gap in our knowledge; however, observations and common sense suggest that the vast majority require a great deal of light in their early years, because, as we have pointed out:

- Ayous-Obeche (Triplochiton scleroxylon K. Schum.), FrakéLimba (Terminalia superba Engl. \& Diels), Framiré (Terminalia ivorensis A. Chev.) and Okoumé (Aucoumea klaineana Pierre) grow at their maximum rate on open ground and do not grow well under shade; the optimum relative light requirements for the species must therefore be in the range of $75 \%$ to $100 \%$;

- Niangon (Tarrietia utilis (Sprague) Sprague), Sipo (Entandrophragma utile (Dawe \& Sprague) Sprague), African Mahogany (Khaya ivorensis A. Chev.), Doussié (Afzelia sp.), Ilomba (Pycnanthus angolensis (Welw.) Warb. subsp. angolensis) and Azobé (Lophira alata Banks ex C. F. Gaertn.) will grow under a high, sparse canopy, but they grow much better on open ground; our own modest experience, backed by numerous observations, suggests that the optimum relative illumination for these species is in the range of $50 \%$ to $90 \%$;

- Avodiré (Turraeanthus africanus (Welw. ex C. DC.) Pellegr.) and Bossé (Leplaea cedrata (A. Chev.) E. J. M. Koenen \& J. J. de Wilde) seem to be the only commercial species that do not do well in full light and grow better under a certain amount of shade.

ROUSSEL has shown that in temperate zones, characteristic shade species such as silver fir (Abies pectinata) still need $5 \%$ to $25 \%$ of relative illumination. We would therefore argue - so far without proof - that saplings of the vast majority of commercially valuable tropical forest species need at least $25 \%$ of relative illumination and at least $\mathbf{5 0 \%}$ in many cases.

6. However, it is not at all certain that lateral illumination is favourable to the growth of young forest saplings, at least those of certain species.

We will now make a comparative study of the silvicultural methods described earlier, in the light of the research results already set out, and attempt to deduce possibilities for improving these methods. Finally, we will describe a new method being developed in the light of these same results.

\section{Improvement methods not seeking immediate natural regeneration}

These are cited here for reference only: as they do not aim for immediate regeneration of the forest, they are not relevant to this part of the study.

\section{Silvicultural methods aiming to promote natural regeneration}

"Selective Management" in Ghana, the A.P.N. method (Amélioration des Peuplements Naturels, or Natural Stand Improvement) in Côte d'Ivoire, and the Tropical Shelterwood System (T.S.S.) in Nigeria are technically very similar. All three, with a few minor differences, are applications of the "seeding cut" technique traditionally used in temperate forests, where the aim is to regenerate a forest by natural seeding in the sunlit clearings opened up by felling. Although we have noted differences in their practical application (the T.S.S. method involves several seeding cuts, called "clearing cuts", followed by a final logging cut, while the selective management method involves the final logging cut only), we believe that ultimately, they have the same advantages and the same fundamental flaws.

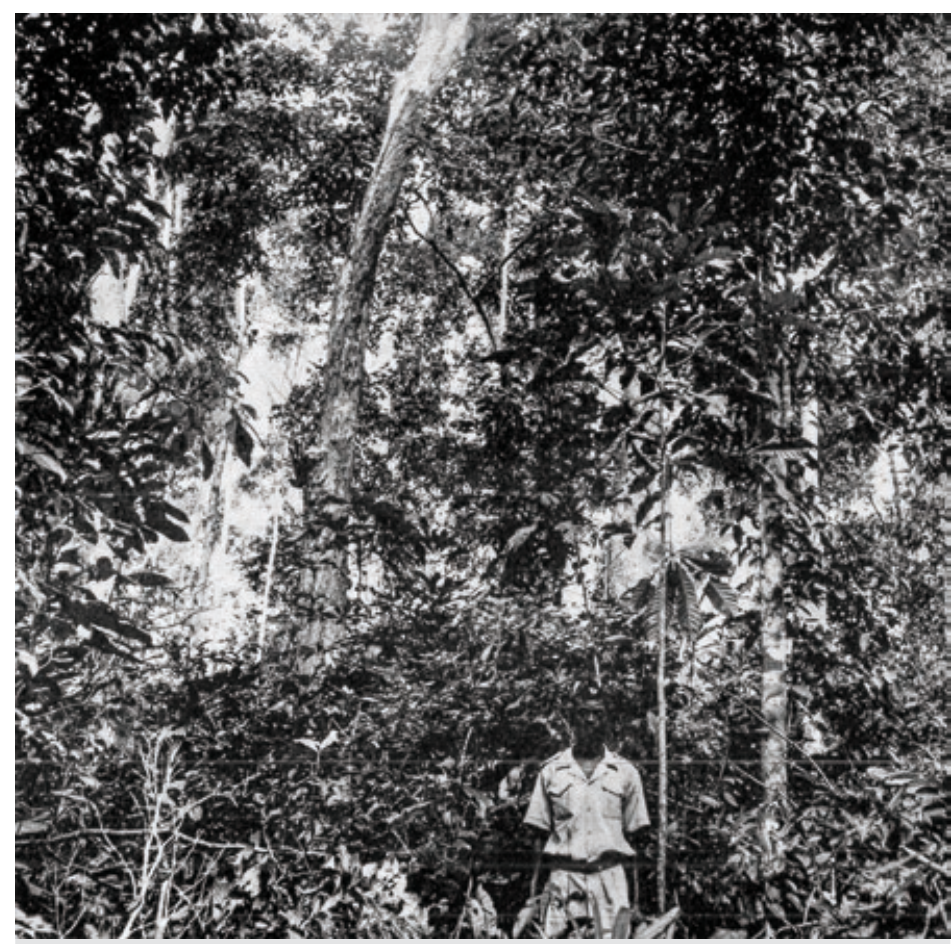

Photo 2.

Natural Stand Improvement (A.P.N. Method). Téké Forest (Côte d'Ivoire). Young Niangon trees (Tarrietia utilis (Sprague) Sprague) growing in plenty of light after recent clearing. Photo Bégué. 


\section{Study of the methods}

\section{A. Advantages}

- These methods require few means, and are therefore economical: there are no nursery or planting costs and the costs of the silvicultural work are largely covered by the timber extracted.

- The forestry work can be conducted simultaneously in many different zones, which can be a considerable advantage in countries with a large population where needs are therefore scattered, but this is hard to achieve with plantation techniques that demand concentrated means in a new country.

- They allow systematic management across large areas of forest, and therefore a sustained rate of production.

- They maintain a forest ambience and improve forest capital over very large areas, because, in theory, the larger the forest areas managed for logging, the more hectares of natural forest are enriched.

\section{B. Drawbacks}

- Work on the same site can become perilously dispersed in time and space: if natural seedlings grow too slowly, the technique may become inapplicable over the years of necessary maintenance work. This is certainly the most serious flaw revealed by experience and explains why these methods have been more or less completely abandoned: after 10 years, the simple forestry work theoretically required to manage a T.S.S. at a rate of 2,500 ha per year will require annual maintenance work over more than $\mathbf{3 0 , 0 0 0}$ ha (Forests Administrator ROBSON cited by R. C. BARNARD). As for worksites where the trees have grown more slowly than planned for, execution of the management plan is likely to become so unwieldy and disorganised that abandoning the method is bound to be considered sooner or later.

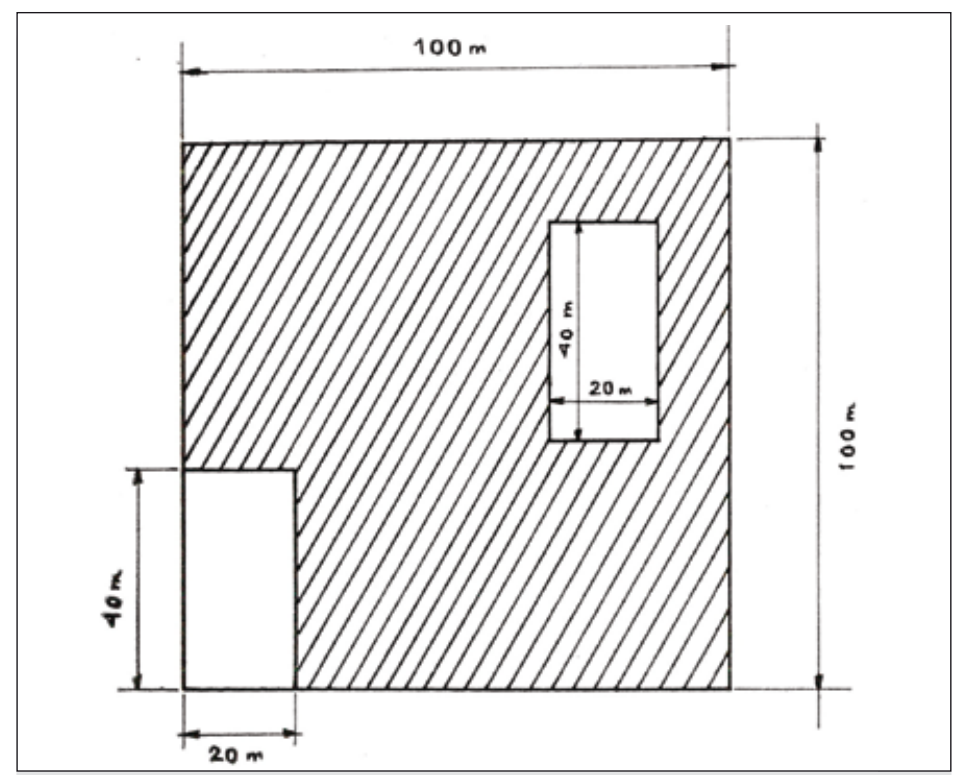

Figure 1.

Diagram of two gaps opened up in 1 ha of dense forest by felling two large trees $40 \mathrm{~m}$ in height with crowns $20 \mathrm{~m}$ in diameter.
- Difficulties with the execution and supervision of clearing work because of the number of different species to be regenerated (at least ten) and the fact that young saplings are not in neat rows, as in a plantation, but dispersed in clearings that are more or less camouflaged by lianas.

- Harmful proliferation of lianas due, as pointed out earlier, to the abundance of light and the large number of standing stems available to support them in regenerating clearings.

- Regeneration is often inadequate because of irregular fruiting: this worsened by the fact that some 10 species are regenerating at once and they rarely fruit abundantly at the same time; this is one of the notable differences compared to natural regeneration techniques in temperate zones, where only one or two species are regenerated at the same time.

- These methods tend to eliminate light-demanding species in favour of shade-tolerant species: this is indisputable because, in our opinion, not enough light reaches the ground during regeneration. Because, as we know, most commercially valuable species thrive in full sunlight or only partial shade, this is clearly a serious drawback. We know, for example, that with natural regeneration methods, Ayous-Obeche (Triplochiton scleroxylon $\mathrm{K}$. Schum.) rarely regenerates because of its requirements for light and its irregular fruiting (once every three or four years); on the other hand, a forest managed in this way becomes enriched in Leplaea cedrata (A. Chev.) E. J. M. Koenen \& J. J. de Wilde, a shade-tolerant species.

- Diminished market value of noble species left standing between regeneration cuts: J. C. MOONEY rightly points out that the isolation crisis causes often irreversible dieback, and that in any case, if these trees are not felled well before the end of the rotation cycle, the delay will result in unacceptable destruction of regenerating saplings. These comments are arguments in favour of the "Selective Management" method, in which logging is planned for every 15 years, or 4 to 5 times per rotation cycle.

- On the other hand, H. C. DAWKINS points out that in any case, any technique involving several cuts in each rotation cycle will produce severe felling damage that considerably reduces the forest's productivity, which the author estimates at a maximum of $1 \mathrm{~m}^{3}$ over $4 /$ ha/year. This argument thus favours the T.S.S., which involves only one clear-cut per rotation.

\section{Discussion}

It is obviously difficult to form a reasoned opinion on such a complex set of problems and to attempt a clear identification of the limiting factors, an understanding of which could help to improve these methods. Nevertheless, we believe that in the final analysis, the paramount limitation is the insufficient amount of light reaching the ground, and we will now attempt to justify this argument as follows:

- With the "Selective Management" method, sufficient light does not reach the ground until the final felling cut; with the T.S.S., on the other hand, this happens five and four years before the final felling cut, partly when undergrowth and lianas are cleared from the understory, and partly when all commercially worthless trees with dense, spreading crowns in the mid and low story are poisoned. To anyone who is familiar with photology measurements in dense tropical forests, this means that the relative illumination obtained has 
to be in the range of $\mathbf{5 \%}$ to $\mathbf{2 5 \%}$, which is much too low to cover the actual needs of pre-existing saplings or the year's new seedlings. Until the felling cut, in other words for four or five years, they will "vegetate" in the deep shade beneath the canopy, growing only half or a third as much as they would have done in full light.

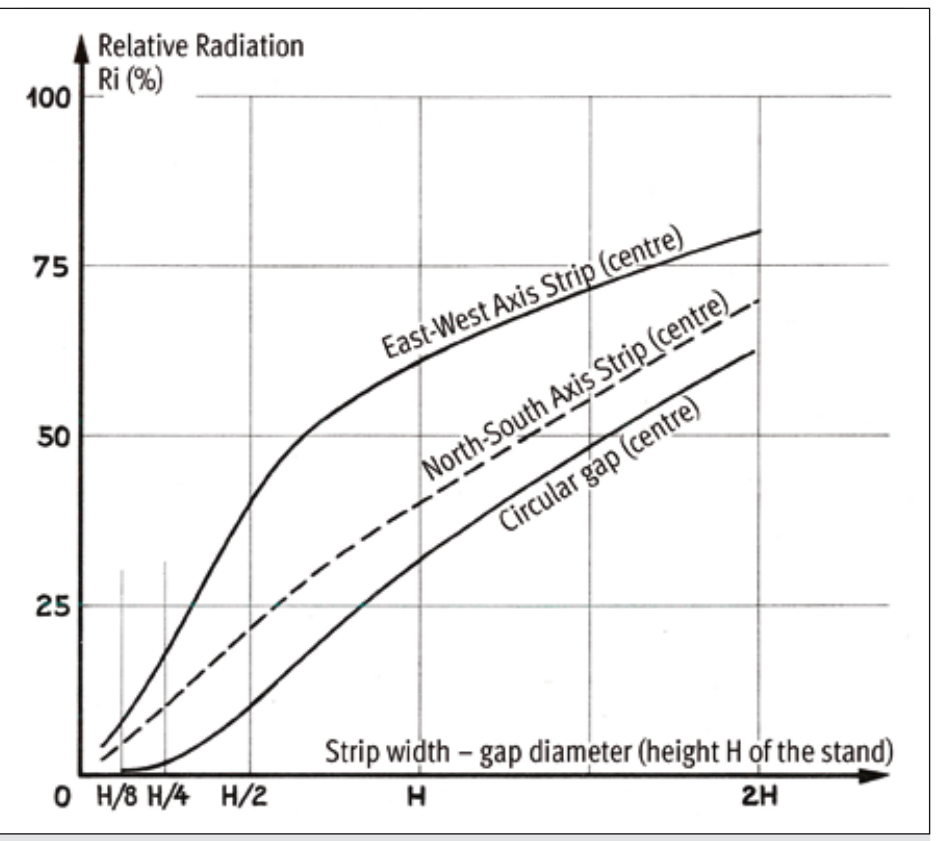

Figure 2.

Graph showing variations in the relative illumination $\mathrm{Ri}$ reaching the ground, according to the width of the plantation row or the diameter of the clearing opened up into a forest stand (expressed in terms of the height $\mathrm{H}$ of the stand).

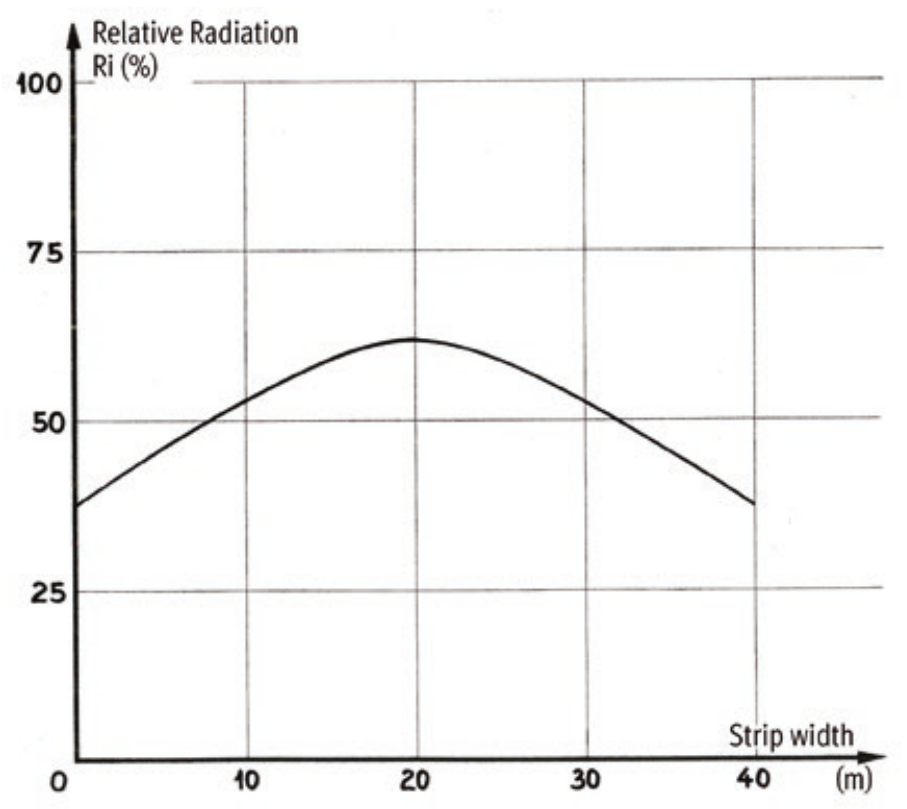

Figure 3.

Variation in the relative illumination Ri reaching the ground along the profile of a strip $40 \mathrm{~m}$ in width $(\mathrm{W}=\mathrm{H})$.
- In the sixth year, with the felling cut, 2 to 4 trees per hectare will be felled on average, thus opening up 2 to 4 more or less rectangular gaps (figure 1), each with an area of $800 \mathrm{~m}^{2}$ on average $(40 \mathrm{~m}=$ height of the tree $\times 20 \mathrm{~m}=$ diameter of the crown), which, over the entire forest and excluding logging roads, represents clearings amounting to $20 \%$ to $40 \%$ of the total forest area. We can consider that a rectangular forest gap will receive an intermediate amount of light between that received by a circular clearing and that received by a strip (which is a rectangle open at both ends); if we refer to the graphs showing relative illumination according to the dimensions of forest gaps (figure 2), we then see that the amount of light reaching the ground along the axis of rectangular felling gaps ranges from $15 \%$ to $\mathbf{3 0} \%$ depending on whether the gap runs North to South or East to West: this amount of light is therefore still not nearly enough for saplings to achieve their maximum growth rate. It should be noted, on the one hand, that this is valid along the axis of symmetry and that the amount of light will be smaller at any other point (figure 3) and, on the other hand, that most of the pre-existing seedlings in these gaps will be crushed as the tree is felled. For all these reasons, therefore, felling gaps are unlikely to favour vigorously growing natural regeneration.

- With the "Selective Management" method, the light brought in by the felling cut will be increased with improvement thinning, which involves clearing around individual useful trees rather than opening up the canopy. With the T.S.S., this will be done by poisoning "uneconomic trees of all dimensions" from the seventh year. Unfortunately, we have never been able to find out exactly how this phrase is interpreted on the ground. However, R. C. BARNARD, the Head of the Malay Forestry Research Department, who visited Nigeria in 1955 to study the T.S.S., notes that "In Nigeria, few trees more than $0.50 \mathrm{~m}$ in

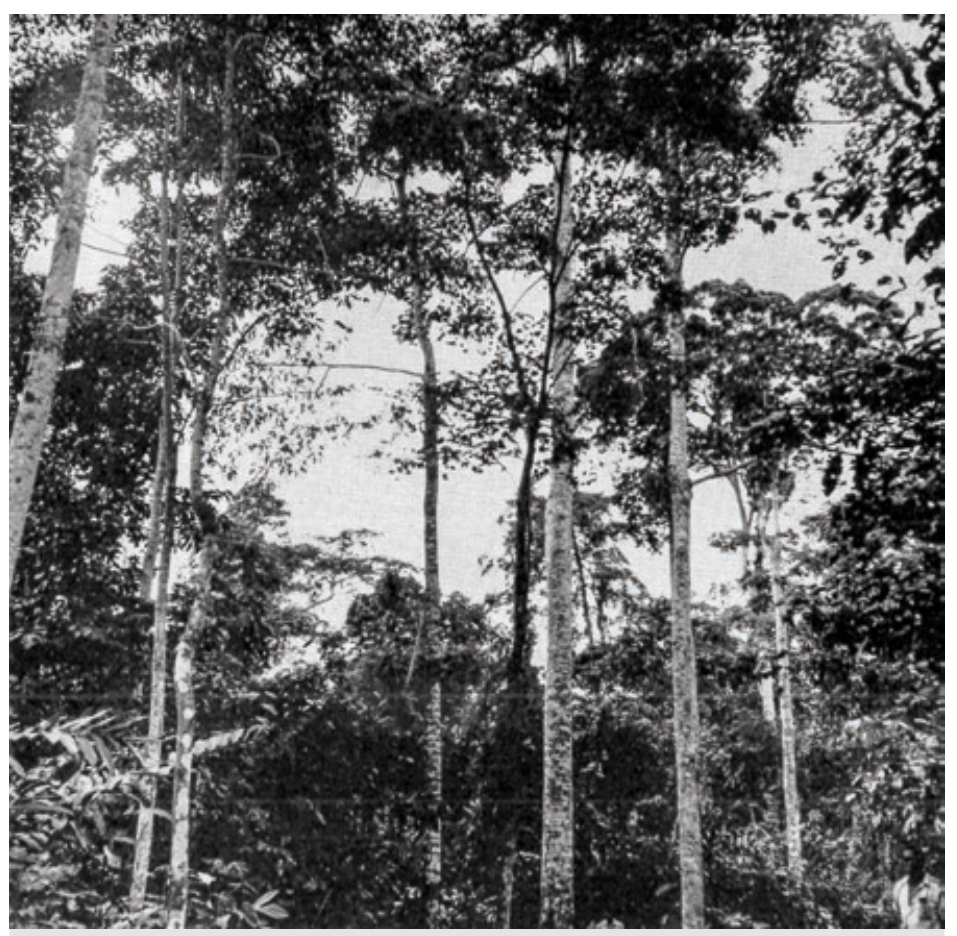

Photo 3.

A 14-year-old plantation of Triplochiton scleroxylon K. Schum. (planted in pairs along the plantation strips). Cameroon. Ottotomo Forest.

Photo Bégué. 
diameter have ever been girdled, and the result is that after the logging and regeneration cuts have been completed, there is still a dominant story (forming a canopy that may be very open to almost closed) of commercially worthless trees that compete to no useful purpose with the new commercially useful growth above and below ground". If these economically worthless trees left standing to protect the soil and prevent lianas from proliferating are added to the trees left standing for their economic value, we can estimate that some $20 \%$ to $60 \%$ of light will reach the ground once the regeneration operations are completed, and that it will be very irregular from one point in the understory to a neighbouring point: these figures in fact correspond to the luxmeter readings we took in 1961 in an A.P.N. parcel in the Téké forest in Côte d'Ivoire.

We can therefore argue that the natural regeneration techniques used up to now in Africa's dense forests, and especially the T.S.S., only give young saplings some $5 \%$ to $25 \%$ of daylight during their first five years, $15 \%$ to $30 \%$ in the felling clearings and $20 \%$ to $60 \%$ from the seventh year, and especially that the illumination is very irregular. This can only result in:

- slow-growing saplings, which increases the duration of maintenance work to an abnormal extent;

- elimination of light-demanding species that cannot thrive in such dim light, and irregular heights and vigour of the naturally regenerating saplings.

For all these reasons, we believe that lack of light is the essential limiting factor for natural regeneration methods.

\section{Possible improvements}

Improvements could be made by:

1. More radical suppression of the canopy, by girdling or poisoning all economically worthless trees more than 15 to $18 \mathrm{~cm}$ in diameter and cutting down trees of the same species less than $20 \mathrm{~cm}$ in diameter with machetes. If conducted simultaneously, these operations should provide about 50 to $75 \%$ of relative illumination.

2. Earlier suppression of the canopy by felling: it is tempting to recommend this operation in the year before commercial felling, but this would be very risky if fruiting is unsatisfactory, so it could be done two years before. After this operation, as only young stems of valuable species would remain standing, the relative illumination of the stand would be at least $75 \%$ and especially, it would be enough to promote regular growth of the saplings that remain.

These modifications of the technique should, in our opinion, result in:

- a shorter period of necessary maintenance work, partly because three years are gained in comparison to the current T.S.S. method, and partly because the saplings will grow faster and thus reduce the number of necessary maintenance operations;

- more abundant, vigorous and evenly distributed regeneration, with a larger proportion of light-demanding species;

- a very significant reduction in harmful liana growth as supporting stems are suppressed, and increased vigour of the new growth as it becomes established naturally and forms a protective blanket over the forest floor (we will return to this in our discussion of a new method in the final part of this article).

\section{Silvicultural methods using regeneration}

For this study, we will discuss the methods in the same order as that used to describe them, from those providing the most light to those providing the least.

\section{The Taungya method}

We first briefly summarise the advantages and drawbacks already described.

\section{A. Advantages}

- Low cost price.

- Maximum light conditions.

- Excellent maintenance conditions (tilling, clearing, etc.). - Convenient solution to land tenure and forest maintenance issues.

\section{B. Drawbacks}

- Poor self-pruning during sapling growth.

- Large increase in parasite attacks.

- Of limited use for light-loving species.

- Limitations on geographical extent due to the distance of villages from cropfields that are widely scattered.

\section{Possible improvements}

Although this method seems to provide saplings with ideal growing conditions (light, tillage), it has been very little used in dense African forests, except with Teak and Cassia siamea (Nigeria), which are savannah rather than dense forest species, with Nauclea diderrichii (De Wild. \& T. Durand) Merr. and Framiré (Terminalia ivorensis) and sometimes with Fraké-Limba (Terminalia superba), Ayous Obeche (Triplochiton scleroxylon) and Bêté (Mansonia altissima). Their exposure to full sunlight inevitably promotes outbreaks of certain forest plantation parasites, such as borers, mealy bugs and psyllids. Massive outbreaks of Hypsipyla robusta borers on Meliaceae and Phytolyma lata (Iroko gall bug) have brought all Taungya plantations of African Mahogany (Khaya ivorensis), Caribbean Mahogany (Swietenia) and Iroko (Chlorophora excelsa) to a halt, and it is not unreasonable to assume that the dieback and bark beetle attacks in Taungya plantations of Framiré in southern Côte d'Ivoire are related to their permanent exposure to full sunlight.

Furthermore, it cannot be denied that self-pruning in trees forming a plantation rather than a forest is very poor. This is a crucial point, because dense forest species capable of self-pruning in full light, or in their own shade to be more accurate, are extremely rare: their lower branches lose their vitality, which is normal, and their leaves gradually wither, but the branches eventually fall before they have dried out completely, leaving snags along the bole that are still partly alive and will only be absorbed by the trunk after several years, forming a large lump that will deform the bole for 5 to 10 years and will often attract further infection (rot), thus further diminishing the value of the tree. BRUNCK, a phytopathologist with the C.T.F.T. who has studied this question, 


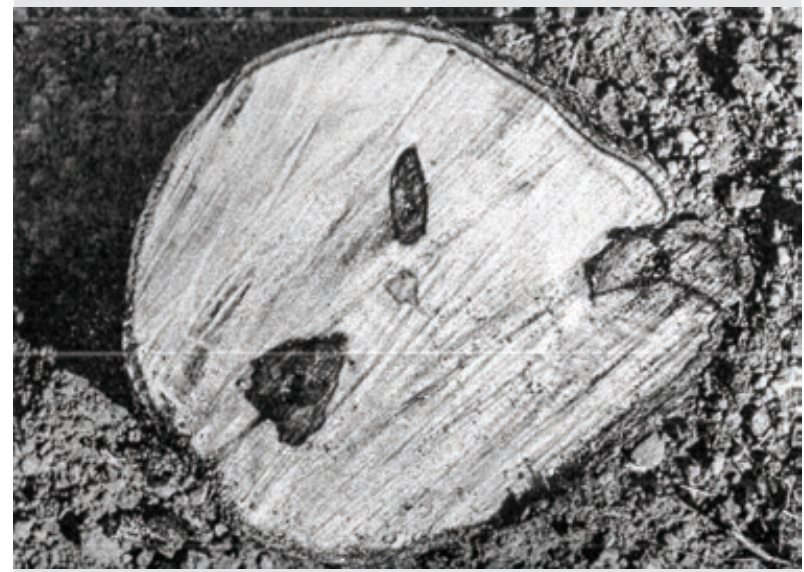

Photo 4.

A pruning defect at a height of $6.40 \mathrm{~m}$. Fraké (Terminalia superba Engl. \& Diels)) plantation (1955) at Bidou III (Kribi), Cameroon.

Photo Brunck, 1965.

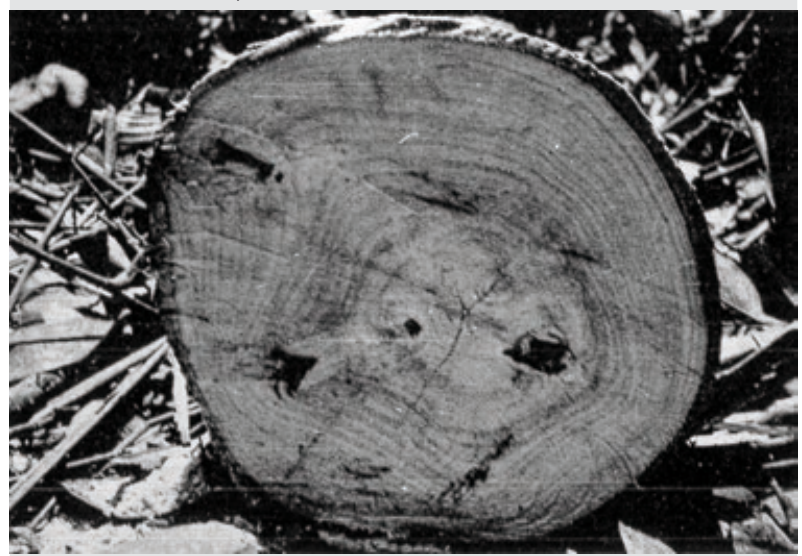

Photo 5.

Makak. Cameroon. A log of Ayous (Triplochiton scleroxylon K. Schum.) with defects at a height of $9.50 \mathrm{~m}$ due to poor pruning.

Photo Brunck, 1965.

has noted that this phenomenon is quite frequent in Terminalia spp., Triplochiton scleroxylon K. Schum., Pycnanthus angolensis (Welw.) Warb. subsp. angolensis and Aucoumea klaineana Pierre; his continuing research will probably show that many other dense forest species are also susceptible. This phenomenon is directly linked to exposure of the trunk to sunlight. Photographs 4 and 5 show some particular examples of malformations in young plantation trees growing without any lateral protection.

These disadvantages of the method could be effectively countered by allowing new growth to develop between the forest saplings, once the farmer has moved onto new ground, as this would protect the boles and promote self pruning. However, because agricultural maintenance work will have removed virtually all stumps, cuttings, etc., the new growth will be slow to become established and will not grow vigorously. It will need to be encouraged by bringing in as much light as possible: this means that the planted saplings must be very widely spaced from the outset, which is contrary to current practice where saplings are planted at distances of $2 \mathrm{~m} \times 2 \mathrm{~m}$ or $3 \mathrm{~m} \times 3 \mathrm{~m}$. We therefore believe that improvements would be possible by:

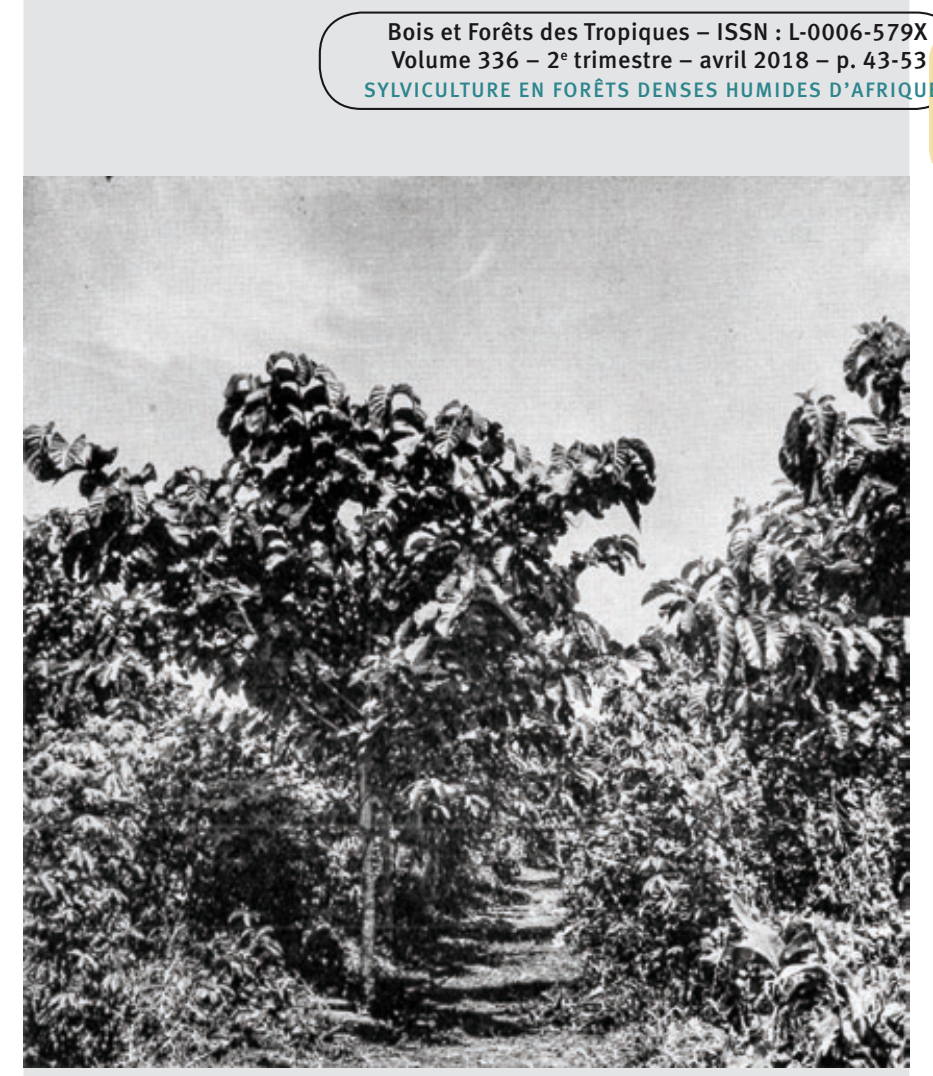

Photo 6.

A 3-year-old "Taungya" plantation of Nauclea diderrichii (De Wild. \& T. Durand) Merr. Sapaba Forest. Nigeria.

Photo Bégué.

- Planting the trees at half their final distance ( $5 \mathrm{~m} \times 5 \mathrm{~m}$ to $7 \mathrm{~m}$ $x 7 \mathrm{~m})$ or at their final distance $(10 \mathrm{~m} \times 10 \mathrm{~m}$ to $14 \mathrm{~m} \times 14 \mathrm{~m})$; - Limiting post-crop clearing to the removal of lianas until the planted saplings are shrouded by new forest growth;

- Limiting the species planted to those with a natural aptitude for self-pruning: Nauclea diderrichii (De Wild. \& T. Durand) Merr., Pycnanthus angolensis (Welw.) Warb. subsp. angolensis, Cedrela odorata L., Terminalia superba Engl. \& Diels, Terminalia ivorensis A. Chev., Tarrietia utilis (Sprague) Sprague. Trials could be conducted for research purposes with Sipo (Entandrophragma utile (Dawe \& Sprague) Sprague) and Ayous-Obeche (Triplochiton scleroxylon K. Schum.).

\section{The Limba and Okoumé methods}

We will discuss these two methods together as they are very similar and the techniques used to prepare the ground are interchangeable: Okoumé trees could be planted in a forest prepared with the "Limba" method (deforestation by manual slash-and-burn) and Limba on "Okoumé" ground (deforested with bulldozers).

It should first be noted that these methods are at quite an advanced stage of development, and although they are obviously not completely finalised, they do not appear to have any critical flaws. The most convincing evidence of this is provided by the 2,000 ha of plantations per year achieved with the "Okoumé" method in Côte d'Ivoire and, in Congo-Brazzaville, the 700 ha per year of reforestation that was being achieved with the "Limba" method before the plantations had to be halted for financial reasons. 
Bois et Forêts des Tropiques - ISSN: L-0006-579X

Volume 336 - $2^{\text {nd }}$ quarter - April 2018 - p. 43-53

SILVICULTURE IN AFRICAN DENSE HUMID FORESTS

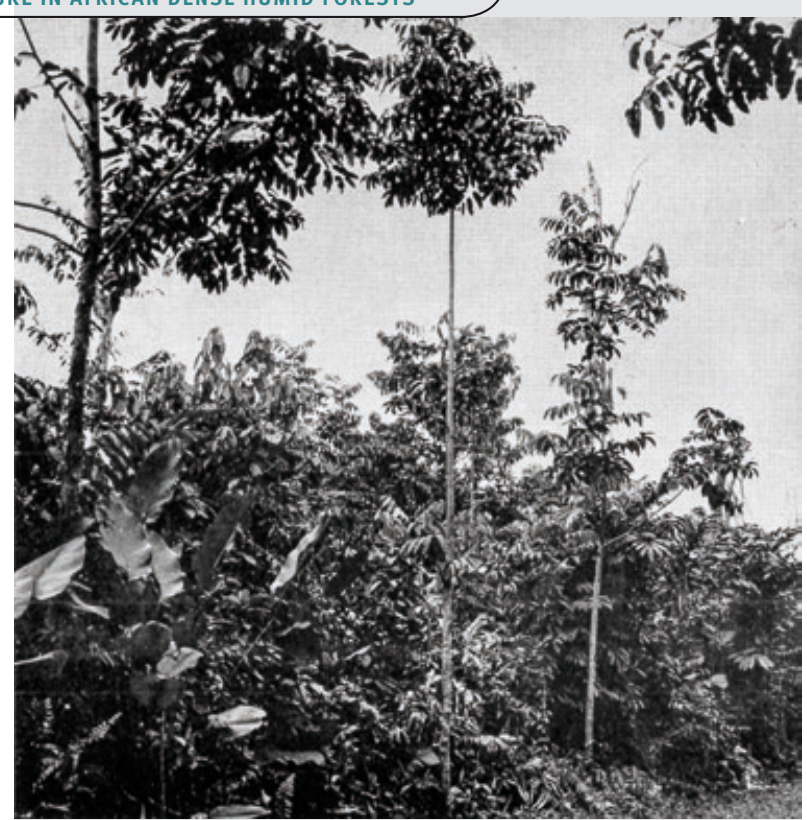

Photo 7.

Aucoumea klaineana Pierre planted as large saplings. N'Koulounga Forest. Gabon.

Photo Bégué.

It could of course be argued that the plantation work involved is relatively costly (65-70 man-days/ha and 5-6 bulldozer hours/ha for the Okoumé method, and 115 man-days/ ha for the Limba method), as opposed to other apparently less costly methods based on natural regeneration or not. This argument is easily countered: these methods are currently the only ones known to succeed over large Okoumé and Limba plantations and the costs are likely to drop with improvements in the techniques. For example, it should be eminently possible to:

- Reduce the costs of "Limba" deforestation, now in excess of 30 man-days/ha, by several man-days/ha by only felling trees up to $30 \mathrm{~cm}$ in diameter instead of 40 to $45 \mathrm{~cm}$, because we believe that the $30 \mathrm{~cm}$ rule, which is accepted for Okoumé, should also be appropriate for Limba, which has very similar needs for light. If feasible, this modification should reduce other costs by reducing the volume of timber to be cleared from the ground before planting (opening up plantation rows, etc.).

- Reduce the costs or the duration of maintenance work thanks to earlier and more radical clearing of umbrella trees (Musanga cecropioides R. Br.), which can encroach with often catastrophic vigour on plantations of Okoumé, and to a lesser extent of Limba. Their proliferation is closely linked to topsoil scraping by bulldozers during the deforestation operation and is also a consequence of the sudden influx of light brought in to give the plantations a good start. We pointed out above that spraying with a $2 \%$ dilution of phytohormones in diesel oil should eliminate the umbrella trees if done towards the second year. In some older plantations where umbrella trees had not been sufficiently cleared, they were overtopping large numbers of Okoumé trees within 10 years and are now dominant. The latter operation would therefore also improve plantation yields.

\section{The Martineau method}

Although this method is only of reference value as it has not been used for 35 years, we will discuss how it could have been improved, if only because, whatever one's opinions about the method, it was the first plantation technique for dense African forests that produced acceptable, albeit irregular, results.

\section{A- Advantages}

- Simplicity of execution, high timber yields per hectare; - Produces even-aged stands.

\section{B. Drawbacks}

- Very high cost price, irregularity of the stands obtained; - High risks of attacks by parasites of pure stands.

\section{Possible improvements}

MARTINEAU undoubtedly realised the importance of the light factor for the growth of dense forest species because, with his method, the entire pre-existing forest was destroyed, so that the young plantations would grow in full light. However, he was clearly not in favour of a sudden influx of full light since he recommended girdling the dominant canopy gradually over the first five years after planting. This meant that the saplings were not growing on open ground until the sixth or seventh year, and that meanwhile, light was brought in very gradually, probably increasing from $5 \%$ to $10 \%$ in the first year to $15 \%$ to $20 \%$ in the second year and so on, to reach $90 \%$ to $100 \%$ in the seventh year. Not only were these amounts of light manifestly insufficient for the trees to thrive but also, the fact that the canopy was necessarily opened up in irregular gaps most certainly caused irregular growth: a five-year-old sapling growing in full light from the start could be several metres taller than another five-year-old sapling growing in the shade of a group of ungirdled trees; more serious still, the former would most probably continue to grow much more vigorously until maturity. The saplings were also very closely planted: 2,000 to 2,500 saplings were planted per hectare, which involved considerable nursery and plantation costs, only to require numerous thinning operations of which the products could not be marketed: this is essentially the reason for the high cost of the method.

In our opinion, the method would have been greatly improved by:

- Suppressing the entire pre-existing forest in the year before planting by felling and girdling, but without burning and leaving the brash to cover the soil in accordance with a technique we will discuss below;

- Planting the saplings at half their final distance ( 5 to $6 \mathrm{~m}$ in each direction);

- Carefully preserving the new growth.

In fact, this is not a modification but a complete change of technique, which would save at least half of the man days required for the MARTINEAU method. 


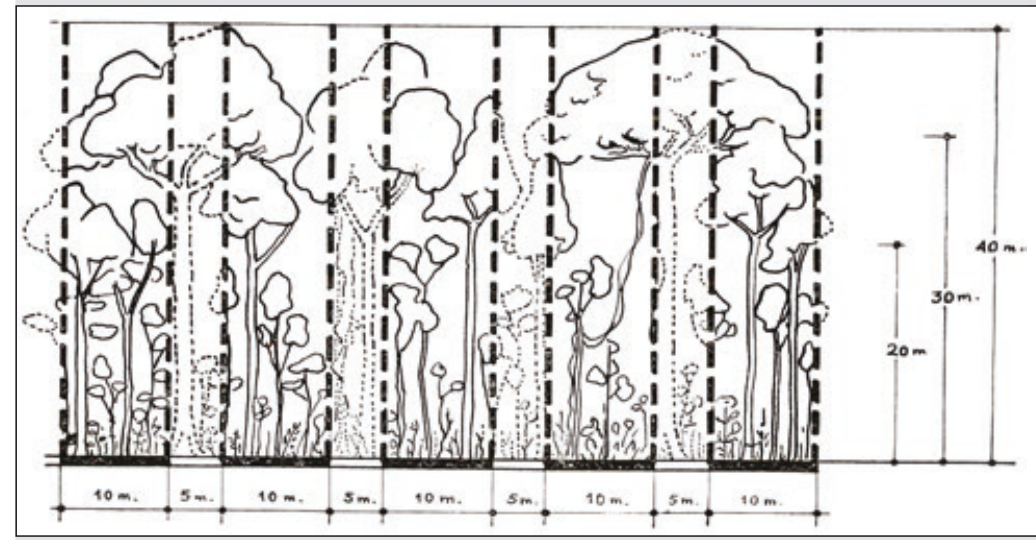

Figure 4-A.

Cross-sectional diagrams of a forest organised into plantation strips and natural forest strips of different standard dimensions: A : $5 \mathrm{~m}$-wide plantation strips, $10 \mathrm{~m}$ apart.

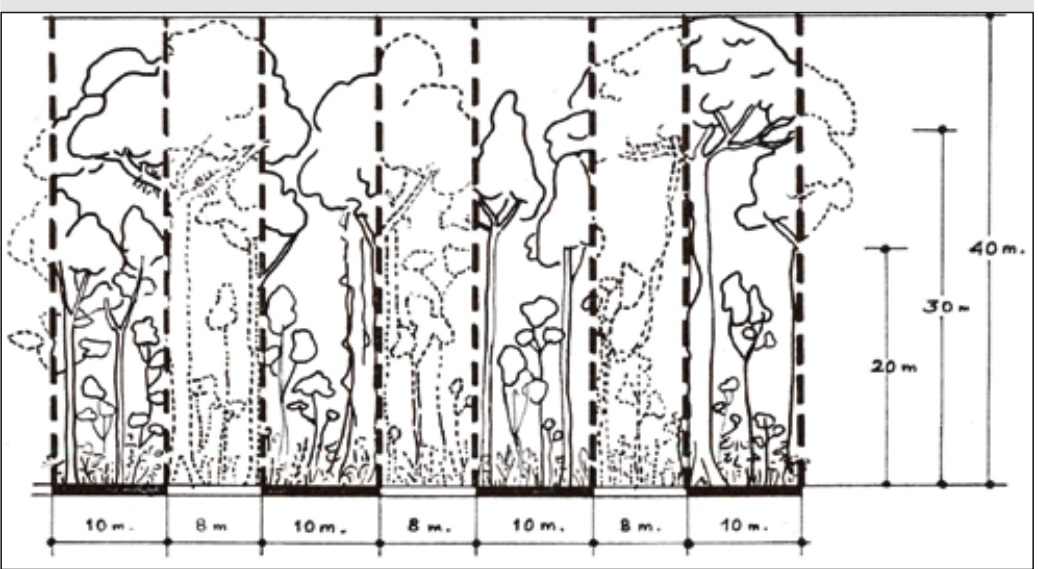

Figure 4-B.

8m-wide plantation strips, $10 \mathrm{~m}$ apart.

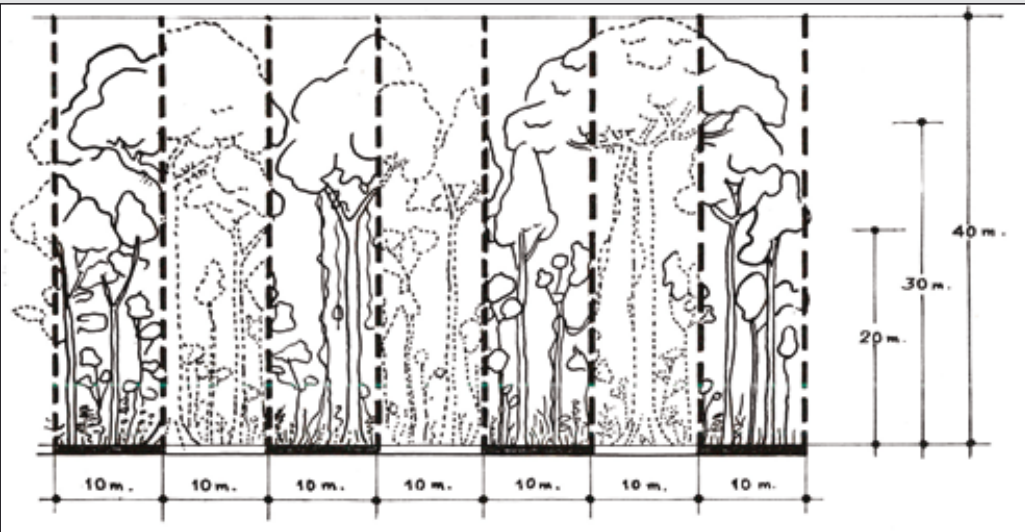

Figure 4-C.

$10 \mathrm{~m}$-wide plantation strips, $10 \mathrm{~m}$ apart.

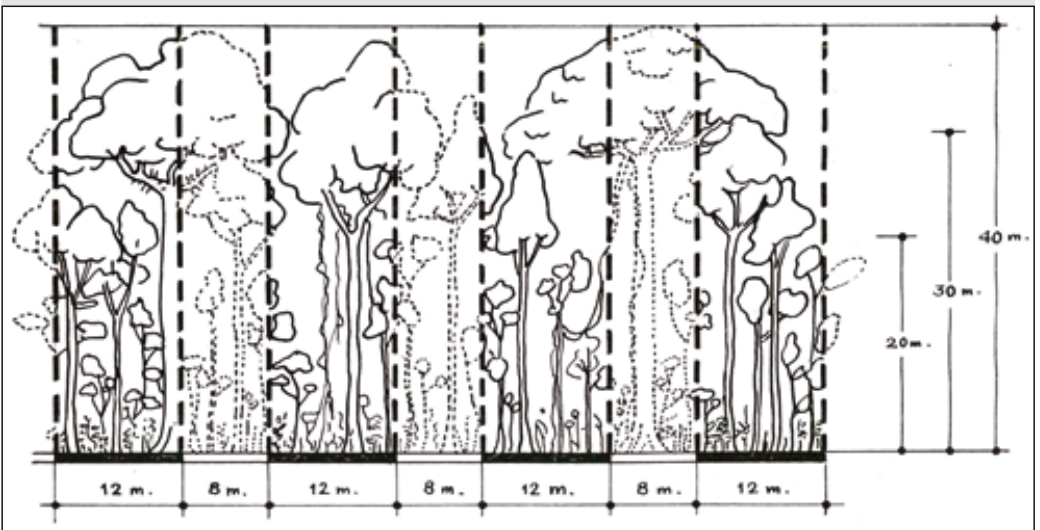

Figure 4-D.

8m-wide plantation strips, $12 \mathrm{~m}$ apart.
Bois et Forêts des Tropiques - ISSN : L-0006-579X

Volume $336-2^{\mathrm{e}}$ trimestre - avril $2018-$ p. 43-53 SYLVICULTURE EN FORETTS DENSES HUMIDES D'AFRIQU

The Narrow Deforested Strips method

This method has attracted a great deal of interest and deserves in-depth study.

\section{A. Advantages}

- Fairly low cost price, Simplicity of execution.

\section{B. Drawbacks}

- Often insufficient sapling growth.

- Excessive duration of maintenance work.

\section{Possible improvements}

It is now universally acknowledged that the fundamental reason for abandoning this method was the poor growth rate of most of the saplings introduced, which therefore required maintenance over a much longer period than planned for, and that the cause - I would say the only cause was the insufficient light available for the saplings to thrive.

We have already touched on this question in our interpretation of the graphs showing relative illumination according to the dimensions of forest gaps: a narrow strip $2.50 \mathrm{~m}$ wide at its base (the usual average width) opened up into a dense forest stand $40 \mathrm{~m}$ in height cannot receive more than $7 \%$ to $8 \%$ of relative illumination (Prof. AUBRÉVILLE found $15 \%$ to $18 \%$ using a spherical actinometer, but this was in a 2-3 m wide strip that was widely open towards the top). We will now discuss this question in more depth based on the graphs in figure 2 :

- A deforested strip $5 \mathrm{~m}$ in width, which is the maximum that can be considered to establish a single row of saplings, still only receives $8 \%$ to $10 \%$ of daylight, or $12 \%$ to $15 \%$ if we include the diffuse lateral light within the forest;

- To increase the amount of daylight in a narrow deforested strip, it can either be widened or the height of the surrounding forest can be reduced (girdling, poisoning); the result will be identical if both corrections are made in the same proportions; - Therefore, to increase the amount of relative illumination from $5 \%$ to $40 \%$ along the axis of a 2.5 m-wide deforested strip running East to West $(W=H / 16)$, the graph in figure 2 shows that the width must be equal to $\mathrm{H} / 2$, which can be obtained either by multiplying the width of the deforested strip by eight or by reducing the height of the surrounding forest to one eighth of its initial height.

To increase the amount of light in the deforested strip, it would therefore seem sensible to act on both parameters simultaneously: this in fact concurs with a recommendation made by AUBRÉVILLE, who in 1946 had advised abandoning the Narrow Deforested Strips method in dense forests and using it only in secondary forests, where the canopy height is lower (20-25 m, as against 
$40 \mathrm{~m})$. But we believe that it could now be applied again in high stands, thanks to a new and inexpensive method of destruction by poisoning: all trees more than $30 \mathrm{~cm}$ to $35 \mathrm{~cm}$ in diameter can be suppressed at a cost of 7-8 man-days/ha using 60 to 70 litres/ha of a $2 \%$ dilution of phytohormones in diesel oil; destroying all trees more than $18-20 \mathrm{~cm}$ in diameter requires 120 130 litres/ha and 12-15 man-days/ha ${ }^{1}$.

But by how much should we increase the width of the strips and decrease the height of the forest to be enriched to obtain the amount of light required for the trees to thrive?

It should first be noted that suppressing the dominant story to bring the height of the forest down to about $30 \mathrm{~m}$ will increase the direct light reaching a narrow deforested strip by the amounts shown by the graphs in figures 2 and 3 , but will also increase lateral illumination by a large proportion because it will eliminate the trunks of large trees, and especially because it will bring light into the lower story, which, in dense forests, is already discontinuous and will be further indented by felling the largest trees. We therefore consider, as a first approximation but unfortunately without the measurements to back up our argument, that reducing the average height to $30 \mathrm{~m}$ will result in $15 \%$ to $20 \%$ of lateral illumination of the row, and that if the height is reduced to $20 \mathrm{~m}$, the figure for lateral illumination will be around $30 \%$ to $35 \%$.

As regards widening the deforested plantation strips, it should be noted that beyond a certain point they would become wide enough to tempt foresters to plant several rows of saplings. However, because the final spacing of the species planted should be between 10 and $15 \mathrm{~m}$, in order to avoid the edge effect that slows down sapling growth and is liable to cause deformities (figure 3), the strips have to be at least $15 \mathrm{~m}$ in width to plant two rows of saplings, or at least $10 \mathrm{~m}$ if a single staggered row is to be kept by thinning the saplings in the two rows alternately. These considerations show that wide strips are not cost-effective when the saplings are planted wide apart, because of the very low ratio between the number of saplings after clearing and the surface area cleared. This comment is all the more important because the Narrow Deforested Strips method should in principle continue to be both extensive and inexpensive. We therefore believe that it would not be reasonable, for many reasons, to increase the width of deforested plantation strips to more than $5 \mathrm{~m}$, and given the different systems shown in the diagram in figure 4, the B-C-D types have to be rejected.

Finally, the distance between the deforested strips has to be established. If the method is to remain extensive, a $15 \mathrm{~m}$ spacing is likely to be the minimum. This would give 50 trees/ha based on standing trees $12 \mathrm{~m}$ apart along the strips; however, the $20 \mathrm{~m}$ and $25 \mathrm{~m}$ spacings recommended by AUBRÉVILLE are still of considerable interest as this would theoretically result in 42 and 34 productive trees/ha. The choice can then be made according to the cost price determined.

As regards the amount of light along the axis of a 5m-wide deforested strip:

\footnotetext{
${ }^{1}$ The same result can be obtained with sodium arsenite but this requires very careful handling.
}

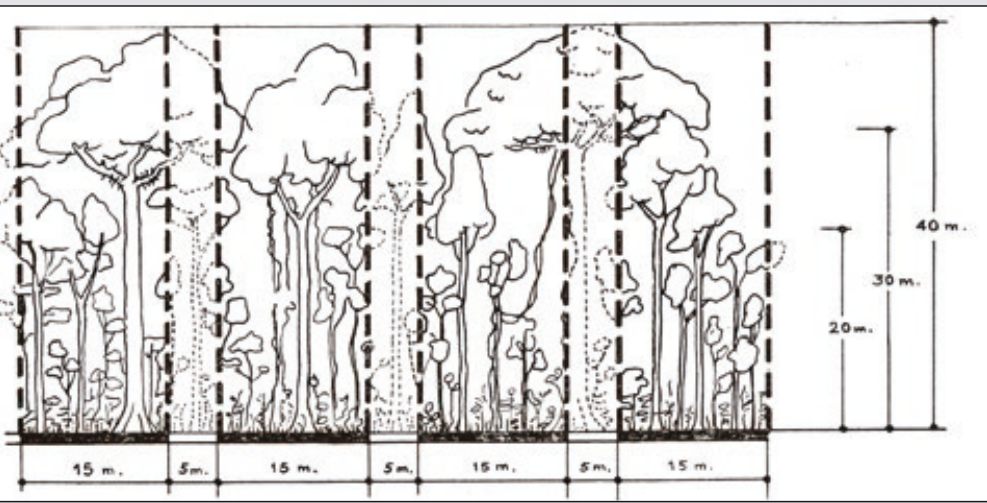

Figure 4-E.

5m-wide deforested strips, $15 \mathrm{~m}$ apart.

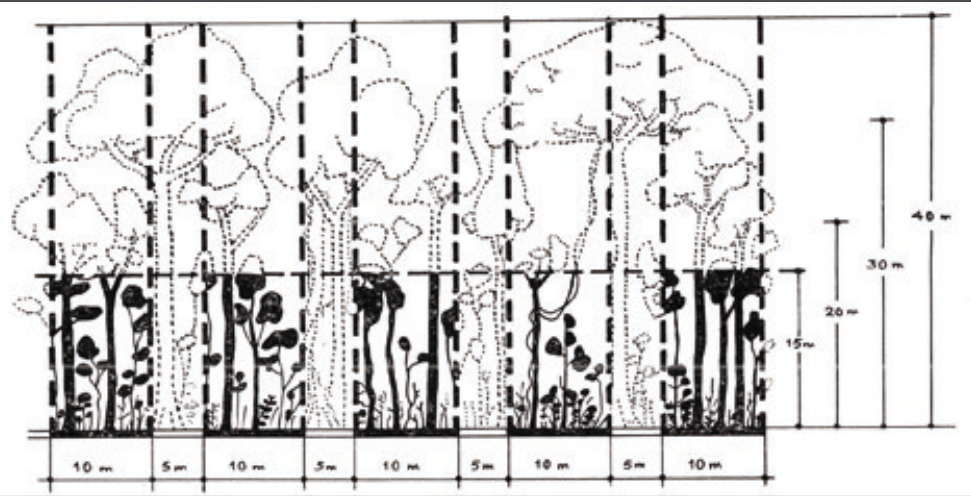

Figures 5.

Cross-sectional diagram of a forest where the height of the dominant story has been reduced to $15 \mathrm{~m}$ and plantation strips opened up as follows:

F: $5 \mathrm{~m}$-wide deforested strips, $10 \mathrm{~m}$ apart.

G: 5 m-wide deforested strips, $15 \mathrm{~m}$ apart.

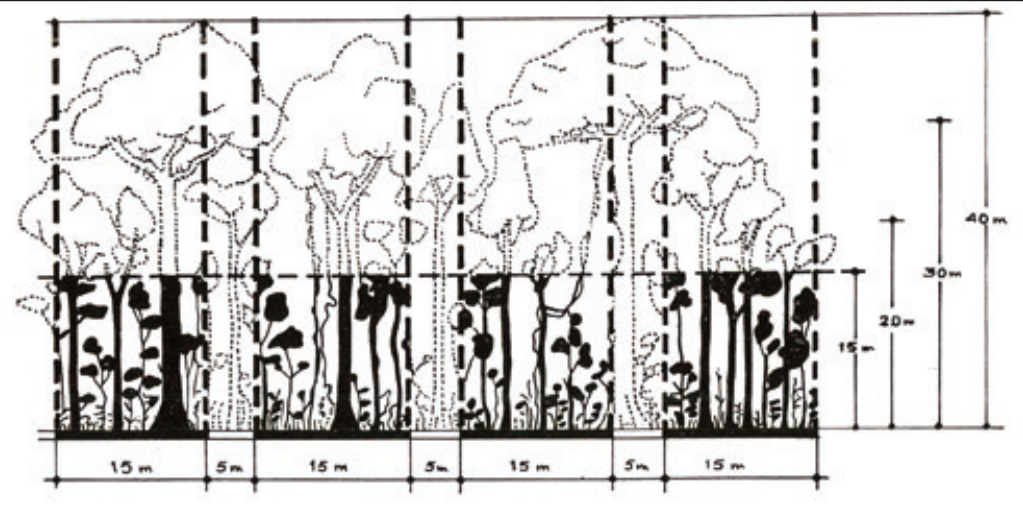

- If the height of the stand is reduced by poisoning to 30 $\mathrm{m}$, the graphs show that direct relative illumination will be about $13 \%$, to which $15 \%$ to $20 \%$ of lateral illumination should be added, bringing the total to $\mathrm{Ri}=28 \%-33 \%$.

- If the dominant stand is reduced to $20 \mathrm{~m}$ in height, the same graphs indicate $18 \%$ of direct illumination, to which should be added $30 \%$ to $35 \%$ of lateral illumination, bringing the total to $\mathrm{Ri}=48 \%-53 \%$.

- Finally, if the height of the stand is reduced to $15 \mathrm{~m}$, direct illumination will increase to $25 \%$ with $35 \%$ to $40 \%$ of lateral illumination, bringing the total to $\mathrm{Ri}=60 \%-65 \%$.

In view of the comments already made on the light requirements of the main commercial species, it would seem that the first two solutions do not provide sufficient light and that the third solution should be adopted, in other words, poisoning large trees to reduce the height of the pre-existing forest to $15 \mathrm{~m}$. 
In practice, the modified Narrow Deforested Strips method would then consist of the following (figure 5):

- In the forest to be enriched, plantation strips $5 \mathrm{~m}$ in width should be staked out, running East to West and 10 m, 15 m or $20 \mathrm{~m}$ apart, depending on the degree of enrichment sought;

- In these $5 \mathrm{~m}$-wide strips, all trees less than 15 to $18 \mathrm{~cm}$ in diameter should be cut down with machetes or axes at knee height (see "New Growth" method below);

- All trees larger than 15 to $18 \mathrm{~cm}$ in diameter across the entire forest should be suppressed by girdling or poisoning (using "Malay" slashes into the bark).

This would only leave standing trees less than 15 to $18 \mathrm{~cm}$ in diameter and generally no more than $15 \mathrm{~m}$ in height, and only between the deforested strips:

- Saplings to be planted $3 \mathrm{~m}$ apart, along the axis of each plantation row;

- Clearing around the saplings with a machetes but leaving a maximum of new growth (Cf. "New Growth" method), and removing lianas and other vegetation encroaching into the rows from the forest strips in between for 6 to 8 years, depending on the nature of the species planted and the success of the plantation. By that age, the saplings should be 8 to $15 \mathrm{~m}$ in height and will be starting to mingle with the dominant forest story growing between the plantation strips.

From the silvicultural point of view, this technique should result in:

- Greatly improved growth given that the trees will be receiving 5 to 6 times more light than with the current Narrow Deforested Strips method, while still growing in a dense forest ambience; - Satisfactory conformation and self pruning, as the saplings will be shrouded by the new growth developing on the floor of the plantation strip below, and by the forest vegetation growing on either side of it at a distance of $2.5 \mathrm{~m}$;

- Sufficient choice for thinning operations, because, taking into account the vegetation destroyed by trees that fall after poisoning (about 1/3), the 8 to 9 trees to be kept per $100 \mathrm{~m}$ plantation strip can be chosen from about 20 to 22 trees in all; - An attractive cost that can be estimated in man-days/ha for an estimated seven years of maintenance on average (see table l).

The low estimate for maintenance costs may seem surprising: it is due to the fact that deliberately leaving new growth at the base of the saplings largely prevents fast-growing invasive species (umbrella trees) from becoming established, so that maintenance work is often limited to clearing lianas ("New Growth" method).

In any case, these numbers are indicative only as there have been no trials as yet of this modified Narrow Deforested Strips method: they simply point to a need for research.

\section{The Evenly Spaced Planting Spot method}

As we have very little information about practical applications of this method, it would not be right to embark on a critical study. However, the illumination graphs show that the square $4 \times 4 \mathrm{~m}$ spots recommended by the authors would receive less than $5 \%$ of relative light if opened up in dense forest; even in secondary forests 15 to $20 \mathrm{~m}$ in height, they would receive no more than $10 \%$ of daylight, lateral illumination included. Until such time as additional information is available, we can therefore only express reservations as to the results to be expected from applying this method in dense forests.

Bois et Forêts des Tropiques - Revue scientifique du Cirad
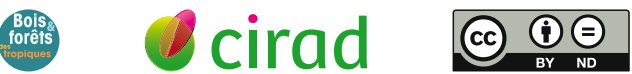

(c) Bois et Forêts des Tropiques (c) Cirad - Campus international de Baillarguet, 34398 Montpellier Cedex 5, France Contact : bft@cirad.fr - ISSN : L-0006-579X

Table I.

Estimated cost in man-days/ha for an estimated seven years of maintenance on average.

Type of work

Reconnaissance of forest parcels Manual clearing, and poisoning

Plantation strips

Nursery

Clearings

Plantation

Maintenance Year 1

Maintenance Year 2

Maintenance Year 3

Maintenance Year 4

Maintenance Year 5

Maintenance Year 6

Maintenance Year 7

Overheads

Total

$0 \mathrm{~m}$ between plantation strips

$15 \mathrm{~m}$ between plantation strips
$20 \mathrm{~m}$ between plantation strips 